\title{
Development of Social Interaction Programs for Students with Special Needs in the Inclusive Education Environment
}

\author{
Nadya Muniroh, Tjutju Soendari, Didi Tarsidi \\ Universitas Pendidikan Indonesia \\ Bandung, Indonesia \\ nadyamuniroh@gmail.com
}

\begin{abstract}
The diversity that is acceptable to all schools is one of the key indicators in the success of inclusive education. Expanding meaningful social interaction opportunities for students with special needs in schools is important to develop. The school where this research conducted does not have systematic and optimal social interaction programs yet, it makes research becomes important to do. This study aims to obtain a description of the objective condition of the social interaction of students with special needs with other school members, and the description of the problem occurs in the social interaction of students with special needs in schools, and also obtaining an objective condition of social interaction program that has been implemented by the school to find out what is the need to be developed. The type of the research is research and development or $R$ and D with ADDIE approach. "A Day Together" or "One Day Together" is a social interaction program for students with special education and education. This program contains activities of the member's school, especially regular students with special needs students for one day starting from the activities in the classroom during the learning process, at the rest time, until the end of the school time in a day.
\end{abstract}

Keywords - inclusive education; social interaction; students with special needs.

\section{INTRODUCTION}

The diversity that can be accepted by all school members is one of the important indicators in the success of inclusive education. Expanding opportunities for meaningful social interaction for special needs students in the school is important. Providing opportunities for students with special needs to interact in the learning process also has a positive impact on the emergence of sympathy from regular students [1], [2], [3], [4], [5]. One of the important indicators in the implementation of inclusive education is participation of all school members which we could be seen from learning process including the participation of students with special needs [6], [7], [8], [9], [10]. The participation of children with special needs can be seen through the meaningfulness of the social interaction process that goes through, both when learning in the classroom and outside of learning activities [11], [12], [13], [14]. Meaningfulness in social interaction is not automatically obtained by students with special needs that need encouragement from people around so that skills in building meaningful social relationships can be fulfilled. Other members of schools in an inclusive education environment have an important role to help students with special needs develop, not only developing on the academic aspect but also on social aspects.

Inclusive education is about fulfilling rights including the right to be actively involved in learning accordance with the abilities and learning needs of each [13], [15], [16], [17], [18]. Integrating through meaningful social interactions that happen in various activities in schools with all the differences that students have in particular with other school members is the right that must be fulfilled. The results of other studies by Terpstra and adding or including social skills programs and strategies for social interaction into inclusive programs is very important for the successes of inclusive programs [19], [20], [10], [21]. Based on the importance of the participation students with special needs in social interaction in schools that provide inclusive education, it is necessary to conduct research for the effectiveness of preparation program [22], [23]. The program will contain an action plan that is able to integrate special needs students with the school community through social interaction more meaningful, both in the learning process as well as the other outside activity of learning.

\section{METHOD}

This study used research and development (research and development). Development research was chosen with the aim of developing products in the form of social interaction programs for students with special needs with other school members in an inclusive education environment [24], [25], [26], [27], [28].

The development of this program applied ADDIE to conduct research and development $(\mathrm{R} \& \mathrm{D})$ systematically [29], [30], [31], [32], [33]. This research was conducted at Hikmah Teladan Middle School in the Cimahi City West Java which school is a school that has had a vision and mission of inclusive education since its inception. Information obtained through the learning process and social interaction of students with special needs that occur in five different classes where there are two to three students with special needs in it, during breaks and in five extracurricular activities attended by students with special needs. 
The school principal, inclusive education coordinator, deputy headmaster for program development, two special education teachers and two subject teachers were the sources of data in the interview process. The data obtained from these sources will be analyzed and become the basic of the program design [2], [34]. After the initial program design is prepared, the program is validated to experts to be developed. The next process is the implementation of the program through an implementation test to find out the relevance of the program to the needs of the school and to find out the ability of school resources to implement the program that has been prepared. Finally, the program was evaluated based on the results of the implementation to formulate the principles of using the program as signs so that when the program is implemented it becomes more effective [6], [32].

\section{RESUlT AND DISCUSSION}

There are still limitation in objective conditions of social interaction special needs students with other school communities in an inclusive educational environment is still limited. Although forms of negative social interaction are rarely found, forms of associative or positive social interactions that appears less varied. Students with special needs still spend more time with special education teachers during the learning process. Beyond the learning process, for example during a break, students with special needs will gather automatically with other special needs students. Extending social interaction to other school members is still difficult to do by students with special needs. It takes expansion of social interaction of students with special needs with other school members so they do not only interact with others special needs students only or only with special teacher.

The problem of social interaction of students with special needs as mentioned in the first point implies that students with special needs are still like "guests" in school, because they are still passive when they have to interact with other school members and can only look more active, more cheerful when interacting with other special needs students. Problems like this can be minimized by providing opportunities for students with special needs to be stimulated more actively involved in various activities at school. Other problems that also arise are parents who are sometimes overprotective. Parental support is no less important, giving children the opportunity to be involved in many activities in school becomes a factor that determines the rate of development of children's social interaction skills.

Social interaction programs that have been run by schools have not been able to make the social interaction of students with special needs with other school members more meaningful and widespread. This is because activities in the program are carried out only once to twice per year, such as outbound and fieldtrip activities. However, to stimulate the expansion of social interaction students with special needs in their daily lives is also difficult to do because of the closes of special needs students with special education teachers or at this school. Program is also need to conduct the program more often so the stimulus for expanding social interaction of students with special needs can be maintained every day.
"One Day Together" is a social interaction program for students with special needs developed by researchers in an inclusive education school environment where research is conducted. This program has passed the validation process to developing program design and has been implemented through an implementation test to strengthen the school's realization of the program. "One Day Together" contains activities of school members, especially regular students with special needs students for one day starting from activities in the classroom during the learning process, during breaks until they go home from school. Students who are on duty to accompany students with special needs will help stimulate students with special needs to be able to interact more actively with the people around them. This program contains interrelated activities starting from activities in the classroom as an effort to make students with special needs participate more actively in the learning process, then there is also an activity at rest which will help students with special needs not only interact with other special needs students but extends to all school residents in an inclusive education environment.

The aim of inclusive education is that if there is concern and cooperation from all parties that can be measured through how all school members in inclusive education environment can interact with each other [6], [35], [36]. This was revealed by with the importance of attendance, participation and achievement of all students [37], [38], [39]. The participation of students with special needs can be seen from how they interact with other school members both inside and outside of school hours [40], [18], [41], [42]. Based on the results of the social interaction of students with special needs with other school members is still limited. There are three main of social interaction happened during research namely during the learning process in class, when taking breaks and in extracurricular activities in general are still not found.

The phenomenon of gathering students with special needs with others special needs students when taking a break at this school again shows the limited form of social interaction. Students with special needs are more comfortable when gathered with each other, students with special needs feel more welcome by their fellow students with special needs, and they seem to have a space that is able to give them the freedom to express feelings when gathered with students with special needs. The limited activities carried out by students with special needs actively with other school members make the forms of social interaction that occur between them less varied. This will make students with special needs who have limitations in social interaction increasingly alienated in schools that should be able to provide wider opportunities to stimulate the development of various aspects of development including aspects of social development.

Most inclusion schools only think about how to process a friendly academic curriculum for students with special needs without taking part in designing a program to develop their social aspects [43], [44], [45], [46], [47] . The characteristics of children who have social competence include: being able to perceive others appropriately, assertive, responsive, and empathetic, having a sense of humor, friendly to peers and polite to adults [8]. These characteristics can be proofed by 
children who have good cognitive function, language function and of course social skills [48], [8], [49], [50], [51].

The limitation of social interaction of students with special needs with other school members is also due to the personal experience of school members who have not received sufficient information regarding students with special needs and inclusive education in general. This research also showed the knowledge on the importance of the need for students with special needs to attend public schools or inclusive schools, and its positive impact if regular students are able to help students with special needs to interact, is still limited, even though regular students are the majority who interact with students with special needs [52], [1], [53], [54], [55]. Students with special needs should spend more time interacting with regular students, some of whom seem unable to establish positive interactions with students with special needs who have many differences with them.

Positive attitudes of school members, especially regular students who interact more with students with special needs, are important because this is one indicator of achieving the goals of inclusive education. This positive attitude can be built and constantly improved through open knowledge of students with special needs will also be programmed.

School is an environment where children not only get academic lessons, but are a place where they gain experience of social and emotional interaction with adults and peers that enable them to foster self-esteem and develop their social competencies [44], [56], [57], [58], [59]. This experience is very important to improve the prospects for success in the future in fostering social relationships, career, and personal achievement [60]. Therefore it is also important for schools to support children's development needs widely [60],[61]. Despite the limitation of social competencies that students with special needs have, schools should be able to accommodate the obstacles [62], [63], [64], [65], [66], [67].

Even though program for students with special needs of stimulating the expansion of their social interaction with regular students have proven effective [64], [68], [69], [70] [20]. The goal of program is able to really make other school members actively interact with students with special needs so that students with special needs no longer feel like guests or riding in school is what the school should do. Modifying existing programs needs to be done to achieve this.

\section{CONCLUSION}

The results of this study concluded into several things: first the conditions of social interaction of students with special needs with other school members are still very limited. Second, students with special needs still feel as guests at school and are less able to establish social relations with other school members than to fellow students with special needs. Third, the social interaction program that has been implemented by schools is cannot to make the social interaction of students with special needs widespread and more meaningful because the frequency of the program so the development of this program is needed. Fourth, "One Day Together" is a social interaction program for students with special needs that have been developed by researchers in the school environment of inclusive education where research is carried out. This program held the activities for school members, especially regular students with students with special needs for one day starting from activities in the classroom during the learning process, during breaks until the students go home from school.

\section{RECOMMENDATION}

Based on the finding of the research, the school's willingness and sincerity was needed in implementing One Day Together social interaction program, which systematically stimulated expansion and maintained the continuity of reguler students' social interactions with special needs students every day. The program that strives for many school members, especially regular students as majority school members, is involved in interacting with students with special needs.

\section{REFERENCES}

[1] R. Opertti and C. Belalcázar, "Trends in inclusive education at regional and interregional levels: issues and challenges," PROSPECTS, vol. 38, no. 1, pp. 113-135, Mar. 2008.

[2] J. S. Owen-DeSchryver, E. G. Carr, S. I. Cale, and A. Blakeley-Smith, "Promoting Social Interactions Between Students With Autism Spectrum Disorders and Their Peers in Inclusive School Settings," Focus on Autism and Other Developmental Disabilities, vol. 23, no. 1, pp. 15-28, Mar. 2008

[3] C. Papaioannou, C. Evaggelinou, and M. Block, "The effect of a disability camp program on attitudes towards the inclusion of children with disabilities in a summer sport and leisure activity camp,' International Journal of Special Education, vol. 29, no. 1, pp. 121-129. 2014

[4] T. A. Rheams and S. K. Bain, "Social interaction interventions in an inclusive era: Attitudes of teachers in early childhood self-contained and inclusive settings," Psychology in the Schools, vol. 42, no. 1, pp. 53-63, 2004.

[5] S. Runcharoen, "The Development of Social Interaction of Children with Autism in Inclusive Classrooms," Procedia - Social and Behavioral Sciences, vol. 116, pp. 4108-4113, Feb. 2014.

[6] M. A. Falvey, and C. C Givner, "What Is An Inclusive School. Alexandria: Associatio for School and Curriculum Development," 2005.

[7] C. Simon, G. Echeita, M. Sandoval, and M. Lopez, T, "He inclusive educational process of students with visual impairments in Spain: An analysis from the perspective of organizations," Journal of Visual Impairment \& Blindness, vol. 104, no. 9, pp. 565-571. 2010.

[8] D. Tarsidi, "Counseling Guidance for the Development of Social Competence of Blind Children," Bandung: Rizqi Press, 2010.

[9] D. Tarsidi, "Chapter 3. Key Concepts: Is Inclusive Education Really?," 2008.

[10] S. Thomazet, "From integration to inclusive education: does changing the terms improve practice?" International Journal of Inclusive Education, vol. 13, no. 6, pp. 553-563, Sep. 2009.

[11] A. M. Alhassan, "Students Social Interactions and Learning in Multicultural School," International Journal of Research in Humanities and Social Studies, vol. 2, no. 11, pp. 6-12, 2015.

[12] L. Cameron, A. Rutland, and R. Brown, "Promoting children positive intergroup attitudes towards stigmatized groups: Extended contact and multiple classification skills training," International Journal of Behavioral Development, vol. 31, no. 5, pp. 454-466. 2007.

[13] C. Acedo, "Inclusive education: pushing the boundaries," PROSPECTS, vol. 38, no. 1, pp. 5-13, Mar. 2008.

[14] D. L. Ferguson, "International trends in inclusive education: the continuing challenge to teach each one and everyone," European Journal of Special Needs Education, vol. 23, no. 2, pp. 109-120, May 2008. 
[15] N. Frederickson, L. Warren, and J. Turner, “'Circle of Friends'-An Exploration of Impact Over Time,” Educational Psychology in Practice, vol. 21, no. 3, pp. 197-217, Sep. 2005.

[16] E. Gaad, "Look who's coming to school: the Emirati student voice in an intervention-based study on inclusion of learners with intellectual disability in Emirati mainstream government schools," Journal of Research in Special Educaational Needs, vol. 15, no. 2, pp. 130-138. 2015.

[17] C. Hurst, K. Corning, and R. Ferrante, "Children's Acceptance of Others with Disability: The Influence of a Disability-Simulation Program," Journal of Genetic Counseling, vol. 21, no. 6, pp. 873-883, Aug. 2012.

[18] M. Koster, S. J. Pijl, H. Nakken, and E. Van Houten, "Social Participation of Students with Special Needs in Regular Primary Education in the Netherlands," International Journal of Disability, Development and Education, vol. 57, no. 1, pp. 59-75, Feb. 2010.

[19] T. Tarmansyah. Guidelines for the Development of Character Education in Inclusive Schools, Padang: Directorate of Special Education and Special Services Development, 2012.

[20] J. E. Terpstra and R. Tamura, "Effective Social Interaction Strategies for Inclusive Settings," Early Childhood Education Journal, vol. 35, no. 5, pp. 405-411, Dec. 2007.

[21] M. S. Zeedyk, P. Caldwell, and C. E. Davies, "How rapidly does Intensive Interaction promote social engagement for adults with profound learning disabilities?," European Journal of Special Needs Education, vol. 24, no. 2, pp. 119-137, May 2009.

[22] E. Godeau, C. Vignes, M. Sentenac, V. EhlingeR, F. Navarro, H. Grandjean, and C. Arnaud, "Improving attitudes towards children with disabilities in a school context: a cluster randomized intervention study," Developmental Medicine \& Child Neurology, vol. 52, no. 10, pp. e236e242, Jul. 2010

[23] I. Halinen and R. Järvinen, "Towards inclusive education: the case of Finland," PROSPECTS, vol. 38, no. 1, pp. 77-97, Mar. 2008.

[24] J. Bell "Doing your research project - Judith, Bell," British Journal of Educational Technology, vol. 37, no. 5, pp. 813-813, Sep. 2006.

[25] J. W. Creswell, Research design quantitative qualitative approach and mixed, Yogyakarta: Student Library, 2010.

[26] I. Hadjar, Basics of Quantitative Research Methodology in Education, Jakarta: Raja Grafindo Persada, 1999.

[27] P. Pargito, Research and development Education Sector, Lampung: University Lampung Social Studies Postgraduate Program, 2010.

[28] S. Sugiyono. Quantitative, Qualitative and Combined Research Methods ( Mix Methods), Bandung: Alfabeta, 2014

[29] N. A. Doobie, "ADDIE Model," American International Journal of Contemporary Research, vol. 5, no. 6, pp. 68 - 72, 2015.

[30] R. M. Branch, Instructional Design: The ADDIE Approach, 2009.

[31] W. R. Borg, and M. D. Gall, Educational Research: An Introduction. Fifthy Edition, New York: Longman, 1989.

[32] N. Prammanee, "Applying ADDIE model for research and development: an analysis of the phase of communicative language of 9 grad students," Proceedings of the Burapha University International Conference, pp. 416-426, 2016.

[33] S. A. Sari and H. Sakdiah, "The development of mind mapping media in flood material using ADDIE model," Journal of Education and Learning (EduLearn), vol. 10, no. 1, p. 53, Feb. 2016.

[34] N. S. Sukmadinata, Educational research methods, Bandung: Teenagers Rosdakarya. 2010.

[35] D. Librarian, Inclusive education and implementation efforts, Jakarta: Luxima Metro Media, 2012

[36] K. M. Lay, Inclusive Education Management, Jakarta: Director General of Higher Education, 2007.

[37] A. F. Mary, and C. G Christine, Creating an inclusive school - Chapter 1. Alexandria, Virginia USA: Association for Supervision and Curriculum Development (ASCD), 2005.

[38] S. Mujito, The Future of Inclusive Education, Jakarta: Ministry of Education and Culture Directorate General of Basic Education, 2012

[39] M. Mudjito, Inclusive Education, Jakarta: Baduose Media, 2012.
[40] C. H. Kennedy, "Social interaction interventions for youth with severe disabilities should emphasize interdependence," Mental Retardation and Developmental Disabilities Research Reviews, vol. 7, no. 2, pp. 122 127, 2001.

[41] S. S. Magnan and M. Back, "Social Interaction and Linguistic Gain During Study Abroad," Foreign Language Annals, vol. 40, no. 1, pp. 43-61, Mar. 2007.

[42] T. MacKay, F. Knott, and A. Dunlop, "Developing social interaction and understanding in individuals with autism spectrum disorder: A groupwork intervention," Journal of Intellectual \& Developmental Disability, vol. 32, no. 4, pp. 279-290, Dec. 2007.

[43] B. Bungin, Sociology of Communication, Jakarta: Kencana, 2006.

[44] D. Damsar, Introduction to Educational Sociology, Jakarta: Kencana, 2011.

[45] E. Lendra, "Regular student perceptions of deaf socialization," vol. 1, no. 3, pp. 187-190, 2013.

[46] N. Muniroh, The relationship between character education achievement and the quality of regular students' social interaction with class VII-x mentally disabled students at banjarmasin public middle school 10 , Thesis at the Department of Special Education, University of Lambung Mangkurat, Banjarmasin, 2014, Not published.

[47] S. Wilkinson, "A broad study from $\mathrm{T}$ he $\mathrm{P}$ articipants "Perspective: A Challenge t o Common Beliefs"," Foreign Language Annals, vol. 31, no. 1, pp. 23 -39. 1998.

[48] J. J. Liu, “Assessing Students' Language Proficiency," Journal of Studies in International Education, vol. 14, no. 5, pp. 528-544, Jun. 2009.

[49] T. Tarmansyah, Inclusion (Education for All), Jakarta: Ministry of National Education, 2007.

[50] C. Wang, "Toward a Second Language Socialization Perspective: Issues in Study Abroad Research," Foreign Language Annals, vol. 43, no. 1, pp. 50-63, Mar. 2010.

[51] L. V. Wiese, and H. Becker, Systematic Sociology, New York: Jhon R. Wiley and Sons, 2011.

[52] M. A. Lamport, "The impact of social interaction on educational outcomes for learning with emotional and behavioral disabilities," European Journal of Business and Social Sciences.,vol. 1, no. 5, pp. 5469. 2012.

[53] N. R. Silton, D. Chera, K. Norley, D. Viletto, S. K. Amir, P. Riley, and A. Untalan, "It's nice to be nice" assessing the efficacy of realities, a educational comic book curriculum new educational puppet show, Marymount Manhattan College, 2017.

[54] S. Skjorten, Towards inclusion of special needs education an introduction, Bandung: UPI Postgraduate Program, 2003.

[55] S. Sugiyo, Interpersonal communication, Semarang: Unnes Press, 2005

[56] H. Djaali, Educational psychology, Jakarta: Bumi Aksara, 2008.

[57] K. Maryati, and J. Suryawati, "Sociology," Jakarta: ESIS, vol 1, 2007.

[58] S. Soekanto, Sociology an introduction, Jakarta: Rajawali Pers, 2006.

[59] Y. Yulianti. Rural sociology, Yogyakarta: Lappera Library, 2003.

[60] P.H. Miller, Theories of developmental psychology $\left(5^{\text {th }}\right.$ ed $)$, New York: Worth Publishers, 2011.

[61] ASB team. Guide i: criteria for standard inclusion school minimum service standards, Yogyakarta: DIY Dikpora Office and ASB Indonesia, 2011.

[62] A. Ahmadi, Learning psychology, Jakarta: Rineka Cipta, 2004.

[63] M. Ali, and M. Asrori, Adolescent psychology, Jakarta: Earth, 2004.

[64] D. Dimitrova-Radojichikj, and B. Sterjadoska-Stojchevska, The Impact of training of typical students: knowledge and attitude towards students with blindness and visual impairments, Journal Plus Education, vol. XIV, no. 1, pp. 243-251, 2016.

[65] W. A. Gerungan, Social psychology, Bandung: Refika Aditama, 2004.

[66] R. Rahardjo. Attitudes of high school students to inclusive education (descriptive study and background to inclusive education in West Java), Bandung: Indonesian Education University, 2013.

[67] E. M. Setiadi, Ilmu sosial \& budaya dasar, Kencana, 2017. 
[68] R. Lewis and E. Burman, "Providing for student voice in classroom management: teachers' views," International Journal of Inclusive Education, vol. 12, no. 2, pp. 151-167, Mar. 2008.

[69] D. Moore and T. Nettelbeck, "Effects of short-term disability awareness training on attitudes of adolescent schoolboys toward persons with a disability," Journal of Intellectual \& Developmental Disability, vol. 38, no. 3, pp. 223-231, May 2013.

[70] J. J. Staniland and M. K. Byrne, "The effects of a multi-component higher-functioning autism anti-stigma program on adolescent boys," Journal of Autism and Developmental Disorders, vol. 43, no. 12, pp. 2816-2829, Apr. 2013. 